\title{
Variation of photostability of DNA-sensitive styrylcyanine dyes caused by $\mathbf{N}$-alkyl functionalization
}

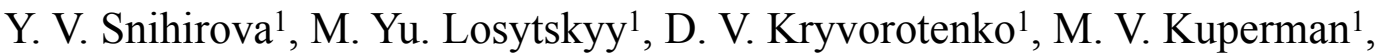 \\ O. V. Moshynets ${ }^{1}$, S. M. Yarmoluk ${ }^{1}$, A. Mokhir ${ }^{2}$, V. B. Kovalska ${ }^{1,3}$ \\ ${ }^{1}$ Institute of Molecular Biology and Genetics, NAS of Ukraine \\ 150, Akademika Zabolotnoho Str., Kyiv, Ukraine, 03143 \\ ${ }^{2}$ Organic Chemistry II, Friedrich-Alexander-University of Erlangen-Nuremberg \\ 42, Henkestr, Erlangen, Germany, 91054 \\ ${ }^{3}$ LLC "Scientific and service firm "Otava" \\ 150, Akademika Zabolotnoho Str., Kyiv, Ukraine, 03143 \\ v.kovalska@gmail.com
}

\begin{abstract}
Aim. Synthesis and characterization of benzothiazole-based styrylcyanines functionalized by different $\mathrm{N}$-alkyl tail groups as potential photostable probes for nucleic acids (NA) detection. Methods. Chemical synthesis, absorption and fluorescence spectroscopy, irradiation with a visible light source, confocal microscopy. Results. Styrylcyanines are weakly fluorescent when free, but in the presence of NA they show emission intensity increase of up to 83 times; the most pronounced emission increase was observed for the dyes Sbt1 and Sbt3 bearing positively charged N-alkyl tail group. Photostability of the dyes Sbt1 and Sbt3 when non-bound to NA is low while binding to DNA results in a strong increase in their photostability. Dyes with uncharged and negatively charged $\mathrm{N}$-alkyl groups are more photostable when free, and DNA slightly affects their photostability. This is also due to low binding of dyes with negatively charged tail groups to DNA. Sbt1 brightly stains cytoplasm and nuclear components (probably nucleoli) of mesenchymal stem cells; therefore this dye may be used to visualize cytoplasmic RNA and nuclear RNA clusters. Conclusions. Variation of chemical nature of $\mathrm{N}$-alkyl tail group allows to design styrylcyanines of different photostability. Functionalized styrylcyanine dyes may be used for detection of nucleic acids in solution and visualization of RNA-containing components in microscopy.
\end{abstract}

Ke y w o r d s: fluorescence, styrylcyanines, NA detection, photostability, microscopy

C) 2020 Y. V. Snihirova et al.; Published by the Institute of Molecular Biology and Genetics, NAS of Ukraine on behalf of Biopolymers and Cell. This is an Open Access article distributed under the terms of the Creative Commons Attribution License (http://creativecommons.org/licenses/by/4.0/), which permits unrestricted reuse, distribution, and reproduction in any medium, provided the original work is properly cited 


\section{Introduction}

Fluorescent detection and visualization of biological molecules, organelles, cells and tissues is a powerful method of research that is widely used for different biomedical and medical purposes [1]. One of the necessary components this method does require is efficient fluorescent probes for the detection of various biological objects; particularly important are nucleic acids (NA) probes [2]. The dyes used as NA probes have to enhance strongly the fluorescence intensity upon binding to target NA molecule, possess high affinity to nucleic acid, low detection limit, high molar extinction coefficient and fluorescent quantum yield when bound, and sufficient photostability when exposed to the high intensity light necessary for microscopy [1].

A common problem with various cyanine fluorescent dyes is low photostability during continuous irradiation in the presence of oxygen that causes irreversible chemical destruction of the fluorophore molecule which thus loses its ability of fluorescence [3, 4]. On the other hand, biological object can be damaged by direct excitation of the luminescent probe in close contact with that object. These processes limit the applicability of fluorescent dyes for practical applications such as fluorescence microscopy and labeling of molecules.

Fluorescent cyanine dyes are molecules commonly used as probes or labels in different biological applications such as imaging, biomolecular labeling, and proteomics [5]. As a result of several advantages of styryl dyes as compared to classical cyanine dyes (better photostability [6], large Stokes shift, relative ease of synthesis), styrylcyanines are extensively studied as possible fluorescent probes for NA detection and visualization. Thus, styrylcyanines were shown to be low-toxic NAs-sensitive dyes, they demonstrated fluorescence intensity enhancement upon binding to NAs as well as high fluorescence quantum yield in the NAs presence [7-10]. Applicability of benzothiazole styryl dyes for two-photon excited fluorescent visualization of living cells was also demonstrated [11]. Earlier, it was shown that the binding affinity of styrylcyanine to NAs could be modified by variation of the structure of $\mathrm{N}$-alkyl tail group of the dye [12-14].

Here, a series of the benzothiazole-based styrylcyanine dyes (Fig. 1) functionalized by different $\mathrm{N}$-alkyl tail groups was synthesized and characterized for their photostability and fluorescent sensitivity to nucleic acids. The long alkyl linkage ( $n$-butyl) was chosen to eliminate the effects of terminal side groups on electronic transitions of chromophore. We studied UV-VIS absorption and fluorescent spectra of these dyes both in the absence and in the presence of NA (both dsDNA and RNA). We evaluated photostability of dyes as a change in the dye absorption after $150 \mathrm{~min}$ of irradiation by VIS source, and analyzed the influence of interaction between dyes and DNA on dyes photostability. By confocal laser scanning microscopy, we evaluated ability of styrylcyanine to penetrate into eukaryotic living cells and visualize cell components.

\section{Materials and Methods}

General. dsDNA (salmon testes) and yeast total RNA were purchased from Sigma-Aldrich Co. Solvents were of analytical grade. ${ }^{1} \mathrm{H}$ NMR 


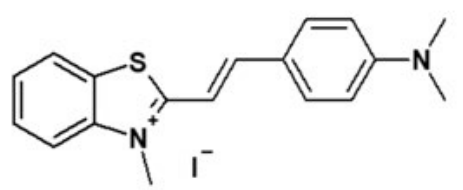

Ref

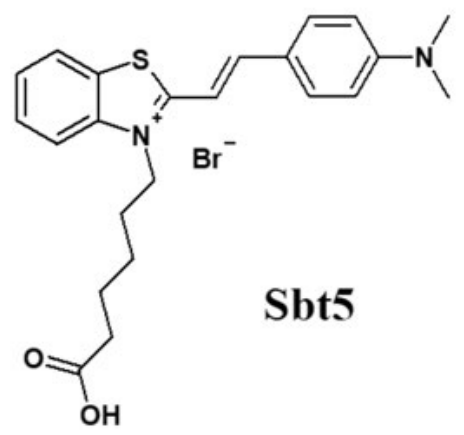

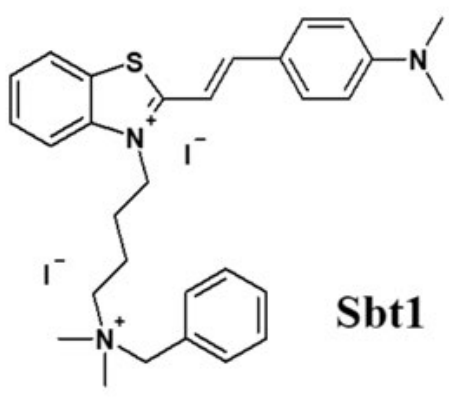
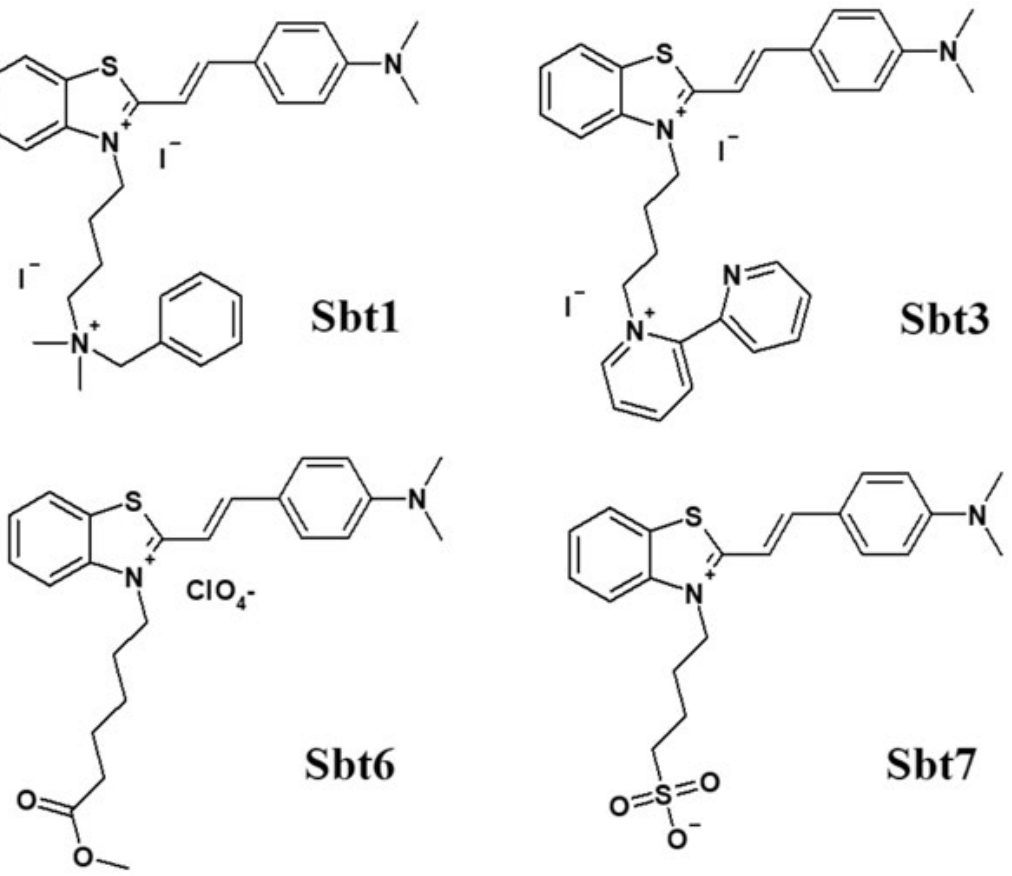

Fig. 1. Structures of the studied dyes.

spectra were recorded on Bruker ARX 400 spectrometers; chemical shifts $(\delta)$ were given in ppm relative to $\mathrm{SiMe} 4.50 \mathrm{mM}$ Tris- $\mathrm{HCl}$ buffer ( $\mathrm{pH}$ 7.9) was used in all assays described.

\section{Synthesis of the dyes}

Referent dye with N-methyl substituent (Ref) was synthesized as described previously [15].

Monomeric benzothiazole styryl dyes (Sbt1, Sbt3) with positively charged tail groups were synthesized as described in [12]. The structures of the dyes were confirmed by ${ }^{1} \mathrm{H}$ NMR spectra, LC-MS and element analysis.

The dyes Sbt5, Sbt6 and Sbt7 were synthesized as follows:

3 - (5 - carboxypentyl) - 2- [2-(4dimethylaminophenyl)-vinyl]-benzothiazol3-ium bromide (Sbt5)
The mixture of $103 \mathrm{mg}(0.3 \mathrm{mmol})$ of 3-(5-carboxypentyl)-2-methylbenzothiazol3 -ium bromide and $44.3 \mathrm{mg}(0.3 \mathrm{mmol})$ of $p$-dimethylaminobenzaldehyde in $0.5 \mathrm{ml}$ of pyridine and catalytic amount of morpholine was boiled during $2 \mathrm{~h}$. The precipitate was filtered off and washed with ethyl alcohol. Yield $80 \mathrm{mg}$ ( $56 \%$ ).

2-[2-(4-dimethylaminophenyl)-vinyl]-3-(5methoxycarbonylpentyl)-benzothiazol-3-ium perchlorate (Sbt6)

$40.5 \mathrm{mg}(0.25 \mathrm{mmol})$ of carbonyldiimidazole were added to $100 \mathrm{mg}(0.21 \mathrm{mmol})$ of $\mathbf{S b t 5}$ in $0.2 \mathrm{ml}$ of DMF at $40^{\circ} \mathrm{C}$. After $5 \mathrm{~min} 0.1 \mathrm{ml}$ of methanol were added and stored during $24 \mathrm{~h}$ at room temperature. The water solution of sodium perchlorate was added. The precipitate was filtered off, washed with water and recrystallized from methanol. Yield $102 \mathrm{mg}$ ( $95 \%$ ). 
2-[2-(4-dimethylaminophenyl)-vinyl]-3-(4sulfobutyl)-benzothiazol-3-ium inner salt (Sbt7)

Mixture of $143 \mathrm{mg}(0.5 \mathrm{mmol})$ of 2-methyl3-(4-sulfobutyl)-benzothiazol-3-ium and $74.5 \mathrm{mg}(0.5 \mathrm{mmol})$ of $p$-dimethylaminobenzaldehyde in $1 \mathrm{ml}$ of $n$-butanol and catalytic amount of morpholine was boiled during $30 \mathrm{~min}$. The precipitate was filtered off, washed with ethyl alcohol and recrystallized from methanol. Yield $190 \mathrm{mg}$ (91\%).

The results of characterization of the dyes Sbt5, Sbt6 and Sbt7 are provided below.

\section{Sbt5}

m. p. (dec.): $>200{ }^{0} \mathrm{C} ;{ }^{1} \mathrm{H}$ NMR (DMSOd6) $\delta(\mathrm{ppm}): \quad 1.45(2 \mathrm{H}, \quad \mathrm{m}), \quad 1.56(2 \mathrm{H}, \mathrm{m})$, $1.82(2 \mathrm{H}, \mathrm{m}), 2.20(2 \mathrm{H}, \mathrm{t}, J=7.5 \mathrm{~Hz}), 3.11(6 \mathrm{H}$, s), $4.79(2 \mathrm{H}, \mathrm{t}, J=7.0 \mathrm{~Hz}), 6.83(2 \mathrm{H}, \mathrm{d}$, $J=8.2 \mathrm{~Hz}), 7.58(1 \mathrm{H}, \mathrm{d}, J=15.3 \mathrm{~Hz}), 7.67(1 \mathrm{H}$, dd, $J=8.0 \mathrm{~Hz}), 7.77(1 \mathrm{H}, \mathrm{dd}, J=7.7 \mathrm{~Hz})$, $7.93(2 \mathrm{H}, \mathrm{d}, J=8.7 \mathrm{~Hz}), 8.10(2 \mathrm{H}, \mathrm{m}), 8.28(1 \mathrm{H}$, d, $J=8.2 \mathrm{~Hz}), 12.10(1 \mathrm{H}$, broad s).

\section{Sbt6}

m. p. (dec.): $181-184{ }^{\circ} \mathrm{C} ;{ }^{1} \mathrm{H}$ NMR (DMSOd6) $\delta(\mathrm{ppm}): 1.44(2 \mathrm{H}, \mathrm{m}), 1.58(2 \mathrm{H}, \mathrm{m}), 1.81(2 \mathrm{H}, \mathrm{m})$, $2.29(2 \mathrm{H}, \mathrm{t}, J=7.7 \mathrm{~Hz}), 3.11(6 \mathrm{H}, \mathrm{s}), 3.54(3 \mathrm{H}, \mathrm{s})$, $4.78(2 \mathrm{H}, \mathrm{t}, J=8.5 \mathrm{~Hz}), 6.83(2 \mathrm{H}, \mathrm{d}, J=8.3 \mathrm{~Hz})$, $7.57(1 \mathrm{H}, \mathrm{d}, J=15.3 \mathrm{~Hz}), 7.68(1 \mathrm{H}, \mathrm{dd}, J=7.8 \mathrm{~Hz})$, $7.77(1 \mathrm{H}, \mathrm{dd}, J=8.0 \mathrm{~Hz}), 7.90(2 \mathrm{H}, \mathrm{d}, J=8.5 \mathrm{~Hz})$, $8.11(2 \mathrm{H}, \mathrm{m}), 8.28(1 \mathrm{H}, \mathrm{d}, J=8.0 \mathrm{~Hz})$.

\section{Sbt7}

m. p. (dec.): $>200{ }^{0} \mathrm{C} ;{ }^{1} \mathrm{H}$ NMR (DMSOd6) $\delta(\mathrm{ppm})$ : undissolved, LC-MS : $\mathrm{m} / \mathrm{z}(\%)=417$ ( $100 \%)[\mathrm{MH}]^{+}$.

Anal. calcd. for C21H24N2O3S2: C, 60.55; H, 5.81 ; N, 6.72. Found: C, 60.21; H, 5.61; $\mathrm{N}, 6.82$.

Spectroscopic measurements. The absorption spectra were recorded on GENESYS ${ }^{\mathrm{TM}}$
20 Visible Spectrophotometer (Thermo Fisher Scientific, USA). The fluorescence excitation and emission spectra were collected on a Cary Eclipse fluorescence spectrophotometer (Varian, Australia). The fluorescence spectra were measured at the excitation and emission slit widths equal to $5 \mathrm{~nm}$. The spectra were acquired using standard quartz cuvettes $(1 \times$ $1 \mathrm{~cm})$ at room temperature $\left(20^{\circ} \mathrm{C}\right)$. All measurements were made at the respective excitation maxima of each dye. Each experiment was performed three times.

Preparation of the solutions. Dye stock solutions were prepared by dissolving the dyes at $2 \mathrm{mM}$ concentration in DMSO. Stock solutions of dsDNA and RNA were prepared by dissolving the NA in Tris- $\mathrm{HCl}$ buffer $(50 \mathrm{mM}$, $\mathrm{pH}$ 7.9) at the concentration of $6.15 \mathrm{mM}$ b.p. for dsDNA and $12.3 \mathrm{mM}$ b. for RNA. Working solutions of free dyes were prepared by dilution of the dye stock solutions with Tris-HCl buffer (pH 7.9) to the concentration of $2 \mu \mathrm{M}$ for absorption and fluorescence spectrophotometry and $5 \mu \mathrm{M}$ for the photostability experiments. The working solutions of dye/NA mixtures for absorption and fluorescence spectrophotometry were prepared by mixing a dye aliquot $(1 \mu \mathrm{L})$ and an aliquot of DNA or RNA stock solutions $(10 \mu \mathrm{L})$ in Tris- $\mathrm{HCl}$ buffer (final concentration of dsDNA was $61.5 \mu \mathrm{M}$ b.p. and RNA $123 \mu \mathrm{M}$ b.). The working solutions of dye/NA mixtures for the photostability experiments were prepared by mixing a dye aliquot $(7 \mu \mathrm{L})$ and an aliquot of DNA solution $(30 \mu \mathrm{L})$ in $3 \mathrm{~mL}$ of Tris- $\mathrm{HCl}$ buffer (final concentration of dsDNA was $61.5 \mu \mathrm{M}$ b.p.)

Photostability. Photostability of the dyes in solution and in the presence of DNA was studied using the laboratory-designed equip- 
ment; its instrumental setup was as follows. The transparent glass vials with the samples (3 $\mathrm{mL}$ of each sample) were placed into the container with the reflecting inner surface, while on the top of the container the irradiating unit was installed. The irradiating unit consisted of 27 light-emitting diodes (blue light, $470 \mathrm{~nm}$ ). To prevent the heating of the samples, cool water was placed inside the container that served as water bath for the glass vials with the samples. The distance between the samples and lamp was $2 \mathrm{~cm}$. This way, photostability of the studied dyes was estimated both in a free state and in the presence of dsDNA (5 $\mu \mathrm{M}$ dye, $61.5 \mu \mathrm{M}$ b.p. dsDNA) in $0.05 \mathrm{M}$ Tris-HCl buffer ( $\mathrm{pH} 7.9)$ and in $0.01 \mathrm{M}$ phosphate buffer ( $\mathrm{pH} 7.0$ ); experiments were also performed for the dyes Sbt1 and Sbt3 in methanol. After irradiation of the mentioned samples during certain time $(0.5,1.5$ and 2.5 hours), the irradiated solutions were placed into the quartz cell, absorption and fluorescence spectra of these solutions were measured, and the values of optical density (D) and fluorescence intensity (I) were obtained. Photostability of the dyes was then characterized by the ratios $\mathrm{D} / \mathrm{D}_{0}$ and $\mathrm{I} / \mathrm{I}_{0}$, where $\mathrm{D}_{0}$ and $\mathrm{I}_{0}$ were optical density and fluorescence intensity of corresponding solutions prepared in the same way without irradiation. For each sample, the photostability measurements were repeated two to four times, and standard deviations were calculated.

Determination of the binding constant $\left(K_{b}\right)$ for the association of $\mathrm{dsDNA}$ with dyes Sbt1 and Sbt6. To estimate the stability of the association of selected dyes Sbt1 and Sbt6 with dsDNA, we conducted fluorescent titration of Sbt1 and Sbt6 with increasing dsDNA concentrations $(0.2$ - $171 \mu \mathrm{M})$. Each experiment was performed three times. The titration curve is provided for the average values along with the standard deviations (SD). For the calculation of binding constant, we used the points corresponding to the excess of DNA. Thus we assumed that only negligible amount of the dye molecules will bind to dsDNA close to each other and affect each other's binding. Based on this assumption, the binding of dye to DNA could be described by the following equilibrium:

$$
d y e+d s D N A \leftrightarrow d y e-d s D N A
$$

the constant of this equilibrium (binding constant, $K_{\mathrm{b}}$ ) can be expressed with the equation (law of mass action [16]) below:

$$
\frac{C_{b d}}{C_{f D N A} \times C_{f d}}=K_{b}
$$

where $C_{\mathrm{bd}}, C_{\mathrm{fd}}$ and $C_{\mathrm{fDNA}}$ are concentrations of a bound dye, a free dye and free dsDNA binding sites, respectively. For the DNA concentrations starting from $20 \mu \mathrm{M}$, that is significantly higher than that of the cyanine dye $(2 \mu \mathrm{M})$, the concentration of free dsDNA base pairs is roughly equal to the total dsDNA concentration $C_{\mathrm{DNA}} ; C_{\mathrm{fDNA}} \approx C_{\mathrm{DNA}}$. Concentration of the free dye in equilibrium is $C_{\mathrm{fd}}=C_{\mathrm{d}}-C_{\mathrm{bd}}$ (where $C_{\mathrm{d}}$ is the total dye concentration). The measured fluorescence intensity $(I)$ of the dye in the presence of dsDNA at the DNA concentration of $C_{\mathrm{DNA}}$ can be expressed with the following equation $I=I_{\max } \times C_{\mathrm{bd}} / C_{\mathrm{d}}+I_{0} \times C_{\mathrm{fd}} / C_{\mathrm{d}}$, where $I_{0}$ is the fluorescence intensity of the dye $(2 \mu \mathrm{M})$ in the absence of dsDNA and $I_{\max }$ is the fluorescence intensity of the dye $(2 \mu \mathrm{M})$ in the presence of the indefinitely large dsDNA concentration. Equation (2) can be transformed into (3): 


$$
I-I_{0}=\frac{A \times K_{b} \times C_{D N A}}{1+K_{b} \times C_{D N A}}
$$

where $\mathrm{A}=I_{\max }-I_{0}$.

$K_{\mathrm{b}}$ and $A$ values can be calculated as approximation parameters by fitting the experimentally obtained data $I-I_{0}$ versus $C_{\mathrm{DNA}}$ by using equation (3). Fitting was performed and the values of $\mathrm{K}$ and $\mathrm{A}$ with their standard deviations were estimated by using Origin 8.0 program.

Eukaryotic cell staining. Mesenchymal stem cells were obtained like it was done before [17]. After transferring the slides to room temperature, the medium was removed. The cells were fixed on microscope slides at room temperature, and incubated with fluorescent dyes for $30 \mathrm{~min}$. The washed cell samples were covered with a cover slip.

Confocal Laser Scanning Microscopy analysis (CLSM). CLSM analysis of the samples was done using Leica TCS SPE Confocal system with coded DMi8 inverted microscope (Leica, Germany). Images were acquired using excitation at $488 \mathrm{~nm}$ and emission collected at 510-605 nm for SYBR Green I, and excitation at $532 \mathrm{~nm}$ and emission collected at 600 $740 \mathrm{~nm}$ for Sbt1.

\section{Results and discussion}

Absorption characteristics of the dyes and dyes' fluorescent properties in free state and in complexes with NA

Earlier a series of styrylcyanine dyes were characterized as the fluorescent probes for DNA detection, and some of them showed good ability to enhance the fluorescent signal upon DNA binding [12]. Spectral properties of the dyes studied in this work (including Sbt1, Sbt3 and Ref dyes reported also in [12]) are provided in the Table 1 . The absorption maxima of the styrylcyanines in $50 \mathrm{mM}$ Tris$\mathrm{HCl}$ buffer $(\mathrm{pH} 7.9)$ are located in the range of 510-524 nm, with moderate values of the molar extinction coefficients at maximum wavelengths $(2.6-7.2) \times 10^{4} \mathrm{M}^{-1} \mathrm{~cm}^{-1}$. Maxima of fluorescence excitation spectra of free dyes

Table 1. Optical properties of styrylcyanine dyes (free and in the presence of dsDNA and RNA) in the same buffer at room temperature.

\begin{tabular}{l|c|c|c|c|c|c|c|c|c|c}
\hline \multicolumn{1}{c|}{ Dye* } & $\lambda_{\max }{ }^{\text {abs }}, \mathrm{nm}$ & $\begin{array}{c}\varepsilon, 10^{4} \\
\mathrm{M}^{-1} \mathrm{~cm}^{-1}\end{array}$ & $\lambda_{\max }{ }^{\mathrm{ex}}, \mathrm{nm}$ & $\begin{array}{c}\lambda_{\max }^{\mathrm{em}} \\
\mathrm{nm}\end{array}$ & $\lambda_{\mathrm{DNA}}{ }^{\mathrm{ex}}, \mathrm{nm}$ & $\begin{array}{c}\lambda_{\mathrm{DNA}}^{\mathrm{em}}, \\
\mathrm{nm}\end{array}$ & $\mathrm{I}_{0}$ & $\mathrm{I}^{\mathrm{DNA}}$ & $\mathrm{I}^{\mathrm{DNA} / \mathrm{I}_{0}}$ & $\mathrm{I}^{\mathrm{RNA}}$ \\
\hline Sbt1 & 524 & 3.8 & 535 & 596 & 557 & 605 & 20.0 & 1660 & 83.0 & 1400 \\
\hline Sbt3 & 515 & 6.0 & 532 & 596 & 562 & 605 & 15.0 & 750 & 50.0 & 680 \\
\hline Sbt5 & 514 & 5.6 & 529 & 592 & 549 & 596 & 31.3 & 100 & 3.2 & 196 \\
\hline Sbt6 & 515 & 7.2 & 529 & 595 & 558 & 601 & 26.8 & 721 & 26.9 & 639 \\
\hline Sbt7 & 510 & 4.3 & 530 & 593 & 547 & 596 & 14.0 & 68.6 & 4.9 & 62.1 \\
\hline Ref & 512 & 2.6 & 539 & 593 & 556 & 604 & 20.6 & 845 & 41.0 & 861 \\
\hline
\end{tabular}

$* C_{\mathrm{dye}}=2 \mu M ; C_{\mathrm{DNA}}=61.5 \mu M$ b.p.; $C_{\mathrm{RNA}}=123 \mu \mathrm{M}$ b.; $50 \mathrm{mM}$ Tris-HCl buffer (pH 7.9); $\lambda_{\max }$ abs — absorption spectra maxima, $\varepsilon$-molar extinction coefficients, $\lambda_{\max }$ ex,$\lambda_{\max }{ }^{\mathrm{em}}$ - fluorescence spectra excitation and emission maxima of free dyes; $\lambda_{\mathrm{DNA}}{ }^{\mathrm{ex}}, \lambda_{\mathrm{DNA}}{ }^{\mathrm{em}}$ - fluorescence spectra excitation and emission maxima of dyes in the presence of DNA; $I_{0}, I^{\mathrm{DNA}}, I^{\mathrm{RNA}}$ - fluorescence intensity (in arbitrary units) of free dyes and of the dyes in the presence of dsDNA and RNA; $I^{\mathrm{DNA}} / I_{0}$ - fluorescence intensity enhancements. 
are shifted for 11-27 $\mathrm{nm}$ to the long-wavelength region as compared to corresponding absorption maxima and are situated at 529$539 \mathrm{~nm}$, whereas the maxima of fluorescence emission spectra are between 592 and $596 \mathrm{~nm}$. The studied styrylcyanine dyes were found to be weakly fluorescent (14-31 a.u.) in the unbound state.

The presence of dsDNA leads to the longwavelength shift of the maxima of fluorescence excitation and emission spectra for 17-30 nm and 3-11 $\mathrm{nm}$ as compared to corresponding maxima of the free dyes; the excitation and emission maxima for the dyes in the presence of dsDNA are thus at 547-562 nm and 596-605 $\mathrm{nm}$ respectively. Upon binding with DNA, the dyes increased their fluorescence intensity up to 83 times (the most significant enhancement was observed for Sbt1 and Sbt3 dyes, the least significant - for $\mathbf{S b t 7}$ and Sbt5). It could be concluded that the less significant values of fluorescence intensity enhancement were observed for zwitterionic dyes (Sbt5 and Sbt7), whereas the other dyes, which are positively charged, demonstrate higher enhancement values, and these values are higher for Sbt1 and Sbt 3 containing the charge +2 compared to the dyes Sbt6 and Ref containing the charge +1 . At the same time, the comparison of the dyes with the same charges points to a negative effect of - $\left(\mathrm{CH}_{2}\right)_{4} \mathrm{COOCH}_{3}$ (comparison of Sbt6 and Ref), and to better effect of $-\left(\mathrm{CH}_{2}\right)_{4} \mathrm{~N}^{+}\left(\mathrm{CH}_{2}\right)_{2} \mathrm{CH}_{2} \mathrm{Ph}$ group (Sbt1) as compared to $-\left(\mathrm{CH}_{2}\right)_{4}$ dipyridyl one (Sbt3). Noteworthy, the presence of RNA (with the same concentration of nucleotide bases) results for the studied dyes (except for Sbt5) in about the same increase in fluorescence intensity as in the presence of dsDNA.

\section{Photostability of the dyes}

To investigate the relationship between molecular structures of the studied styrylcyanine dyes and their photostabilities, the effect of irradiation of the dyes solutions by the blue light (working wavelength about $470 \mathrm{~nm}$ ) on the absorption and fluorescence spectra of these solutions was studied. The change of the characteristics (maximum wavelength and optical density) of the absorption spectra of the dyes (free and in the dsDNA presence) after 30 minutes and 150 minutes of irradiation could be seen in the Table 2 .

It could be seen from the Table 2 that 30 min irradiation leads to a small shift of the absorption maxima of some samples. At the same time, irradiation during 2.5 hours results in the short-wavelength shift for 1-17 nm (without any change in the peak shape) for all the studied samples. Noteworthy, for the dyes Sbt1, Sbt3 and Ref the shift for the free dye (10, 15 and $17 \mathrm{~nm}$ respectively) significantly exceeds that for the dye in dsDNA presence (3, 4 and $9 \mathrm{~nm}$ respectively). As for the dyes Sbt5, Sbt6 and Sbt7, the shift for the dyes in the dsDNA presence $(3,3$ and $1 \mathrm{~nm}$ respectively) is about the same as for the free dyes ( $3 \mathrm{~nm}$ for all three dyes).

Besides the wavelength shift, irradiation of the dyes solutions also leads to the change in the optical density of the dyes. For all the dyes (except Sbt7), the optical density after 30-min irradiation became equal to $63-95 \%$ of the corresponding value before irradiation for free dyes (the lowest values were observed for Sbt1 and Sbt3) and 75-93 \% for dyes in the presence of DNA (Table 2; Fig. 2). Noteworthy, for the dyes Sbt1 and Sbt3, the addition of DNA caused noticeable increase in photosta- 
Table 2. Optical density (D) of dyes in a free state and in the presence of dsDNA

\begin{tabular}{|c|c|c|c|c|c|}
\hline Dye & $\lambda^{0}{ }_{\max }(\mathrm{nm})$ & $\lambda^{0.5}{ }_{\max }(\mathrm{nm})$ & $\mathrm{D} / \mathrm{D}_{0} * \times 100 \%[0,5$ hour $]$ & $\lambda^{2.5}{ }_{\max }(\mathrm{nm})$ & $\mathrm{D} / \mathrm{D}_{0} \times 100 \%[2,5$ hours $]$ \\
\hline Sbt1 & 524 & 522 & $66 \pm 7$ & 514 & $11 \pm 11$ \\
\hline Sbt1+DNA & 549 & 548 & $89 \pm 4$ & 546 & $42 \pm 19$ \\
\hline Sbt3 & 516 & 513 & $63 \pm 4$ & 501 & $8 \pm 8$ \\
\hline Sbt3+DNA & 527 & 527 & $75.2 \pm 1.4$ & 523 & $35 \pm 19$ \\
\hline Sbt5 & 514 & 514 & $95 \pm 5$ & 511 & $81 \pm 15$ \\
\hline Sbt5+DNA & 514 & 514 & $93 \pm 3$ & 511 & $74 \pm 10$ \\
\hline Sbt6 & 515 & 515 & $88 \pm 11$ & 512 & $61 \pm 6$ \\
\hline Sbt6+DNA & 521 & 520 & $86 \pm 11$ & 518 & $59 \pm 6$ \\
\hline Sbt7 & 517 & 517 & $127 \pm 22$ & 514 & $116 \pm 14$ \\
\hline Sbt7+DNA & 518 & 518 & $113 \pm 23$ & 517 & $129 \pm 29$ \\
\hline Ref & 513 & 508 & $75 \pm 15$ & 496 & $38 \pm 46$ \\
\hline Ref+DNA & 523 & 524 & $80 \pm 5$ & 514 & $44 \pm 4$ \\
\hline
\end{tabular}

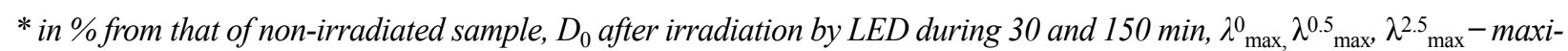
mum wavelengths of absorption spectra for non-irradiated samples and those irradiated during 30 and $150 \mathrm{~min}$

bility, whereas for other dyes the mentioned effect exceeding the experimental error was not observed. As for the dye Sbt7, irradiation during 30 minutes caused an increase in the optical density of this dye both in the presence and in the absence of DNA (Fig. 3). This result could be explained by bad solubility of Sbt7

$\boldsymbol{A}$

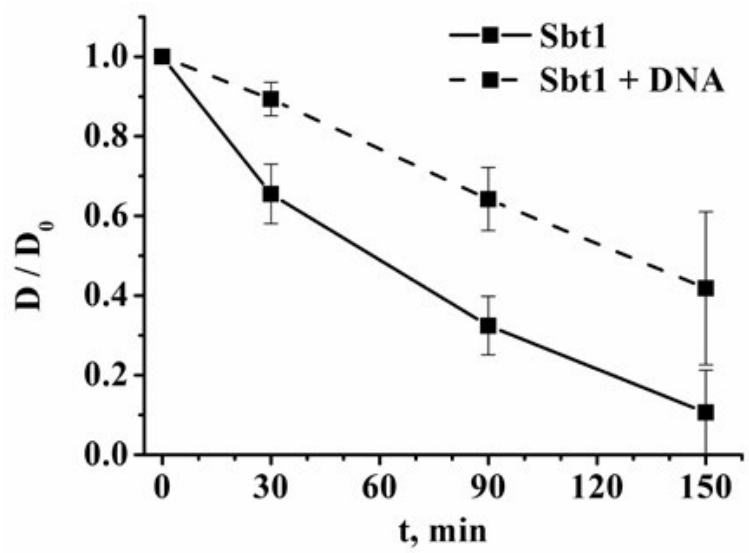

in the buffer, which could be increased because of local heating as the result of light absorption by the low-fluorescent dye.

After 150 min of irradiation, for all the dyes (except Sbt7) further photodestruction was observed, and two tendencies described above became still more noticeable (Table 2, Fig. 2).

B

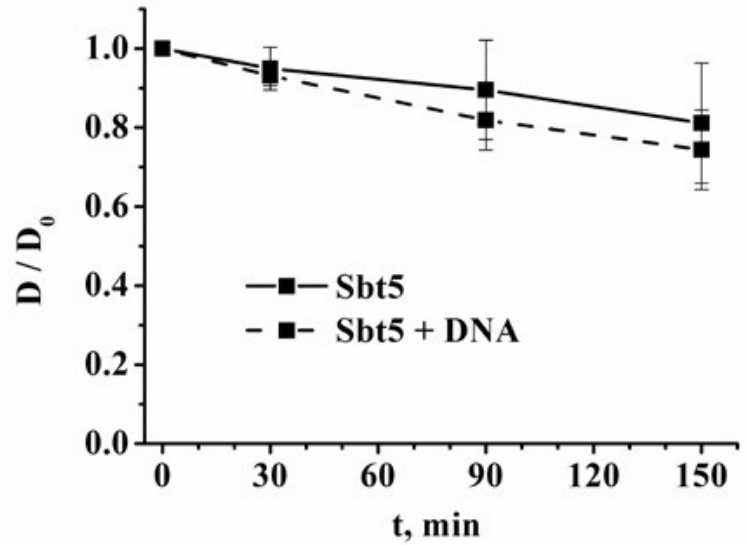

Fig. 2. Graphs of the ratio $D / D_{0}$ upon irradiation time, where $D$ is the optical density (at maximum wavelength) of the sample after irradiation during $0,30,90$, and $150 \mathrm{~min}$, and $\mathrm{D}_{0}$ is the optical density of the sample before irradiation, for dyes $\operatorname{Sbt1}(\boldsymbol{A})$ and $\mathbf{S b t 5}(\boldsymbol{B})$ with and without dsDNA in solution $\left(\mathrm{C}_{\mathrm{dye}}=5 \mu \mathrm{M}, \mathrm{C}_{\mathrm{dsDNA}}=61.5 \mu \mathrm{M}\right.$ b.p $)$ in Tris- $\mathrm{HCl}$ buffer (C=0.05 M, pH 7.9). 
First, strong difference in a decrease of the optical density for the free dyes took place. For Sbt1 and Sbt3 the optical density after $150 \mathrm{~min}$ of irradiation becomes respectively $11 \%$ and $8 \%$ of corresponding value before irradiation whereas for Ref, Sbt6 and Sbt5 this value is $38 \%, 61 \%$ and $81 \%$ respectively. Second, an addition of DNA causes a strong increase in the photostability for the same dyes Sbt1 and Sbt3 (optical density is $42 \%$ and $35 \%$ respectively compared to the corresponding values before irradiation), whereas for other dyes this increase is either absent or below the experimental error. As for the dye Sbt7, irradiation during $150 \mathrm{~min}$ does not make the changes in its optical density exceeding the experimental error both for free dye and in DNA presence (Table 2, Fig. 3).

Thus, the obtained results regarding the irradiation effect on the dyes absorption spectra

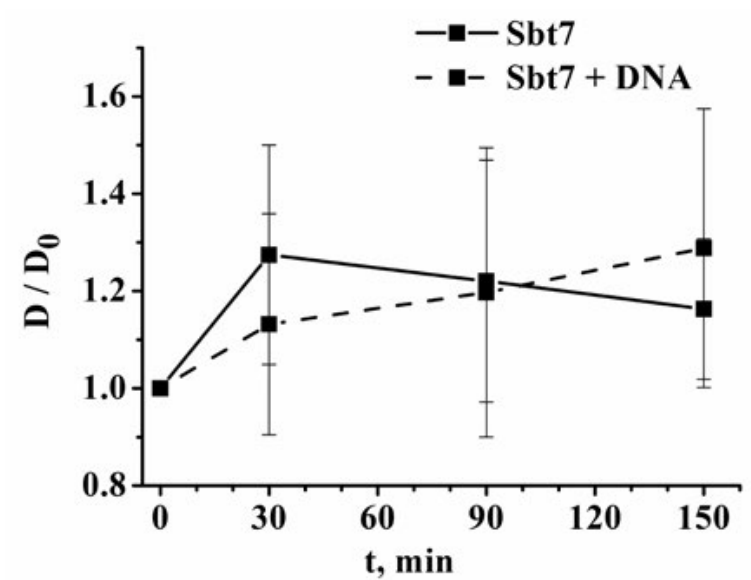

Fig. 3. Graph of the ratio $\mathrm{D} / \mathrm{D}_{0}$ upon irradiation time, where $\mathrm{D}$ is the optical density (at maximum wavelength) of the sample after irradiation during $0,30,90$, and $150 \mathrm{~min}$, and $\mathrm{D}_{0}$ is the optical density of the sample before irradiation, for the dye $\mathbf{S b t} \mathbf{7}$ with and without dsDNA in solution $\left(\mathrm{C}_{\mathrm{dye}}=5 \mu \mathrm{M}, \mathrm{C}_{\mathrm{dsDNA}}=61.5 \mu \mathrm{M}\right.$ b.p $)$ in Tris- $\mathrm{HCl}$ buffer $(\mathrm{C}=0.05 \mathrm{M}, \mathrm{pH} 7.9)$. could be summarized as follows. First, it could be seen that the dyes with aromatic charged substituents Sbt1 (with N-alkyldimethylbenzyl substituent) and Sbt3 (with N-alkyldipyridyl substituent) bearing double positive charge are, on one hand, the least photostable in free state and, on the other hand, an addition of DNA to these dyes results in a strong increase of their photostability. On the other hand, the unsubstituted dye Ref as well as the dye Sbt6 (with uncharged aliphatic substituent) both bearing single positive charge are more photostable in free state than Sbt1 and Sbt3, whereas the dyes Sbt5 and Sbt7 (which are zwitterionic due to negatively charged $\mathrm{N}$-substituents), are the most photostable. At the same time for these four dyes (Ref, Sbt6, Sbt5 and Sbt7), the changes in their photostability induced by the DNA presence do not exceed the experimental error.

Though the detailed mechanisms of dyes photodestruction are not completely understood, this process is generally considered to be connected with the transition of the excited dye to the triplet state. The dye in the triplet state can then either induce reactive oxygen species which will further damage the dye, or directly react with redox-active molecules present in the solvent [4]. Thus, the obtained dependence of the free dye photostability on its electric charge and/or substituent could be explained by the effect of charge/substituent on chromophore interaction with the possible redox-active molecules or generated reactive oxygen species in the solution (due to the interaction of the substituent group either with the chromophore, or with reactive molecules). It should be added that photostability of the free dyes in phosphate buffer (data not pre- 
sented) does not essentially differ from corresponding values in Tris-HCl buffer. At the same time, photostability of Sbt1 and Sbt3 in methanol is significantly higher (optical density after 150 min of irradiation is $89 \pm 7 \%$ and $103 \pm 2 \%$ respectively of corresponding values before irradiation) than in both Tris and phosphate buffers. These facts could point to the role of the redox-active molecules present in water in photodestruction of the dyes.

As for the different influence of the DNA presence on the photostability of different studied dyes, two factors should be considered. First, the dyes Sbt1 and Sbt3 which increase their photostability in the DNA presence have also the highest increase in their fluorescence intensity upon DNA addition (Table 1). Taking into account that these dyes possess double positive charge, we could suppose that they bind to DNA with higher affinity as compared to other dyes. If so, the reason of the increase in the dye photostability should be its binding with DNA (despite the anticipated increase in the excited state lifetime). The possible explanation could be the restriction (at least partial) by DNA of the access to the dye molecule of the generated reactive oxygen species or redoxactive molecules. On the other hand, one cannot also exclude the fixation of the dye structure upon binding that does not permit the excited dye to acquire the reaction-suitable conformation. As for other studied dyes which either contain single positive charge or are zwitterionic, we could suppose that they bind with DNA with lower affinity. This means that lower percent of these dyes form complexes with DNA, and thus DNA influence on the dyes photostability is less significant. Another factor is that the dyes Sbt5, Sbt6 and Sbt7 are much more photostable in a free state as compared to Sbt1 and Sbt3, so that the influence of DNA on their photostability would not be as noticeable for the former dyes as for the latter ones.

For the dyes Sbt1, Sbt3 and Ref in the presence of dsDNA, we also compared the influence of irradiation on dye optical density and on its fluorescence intensity (Table 3). It is seen from the Table 3, that while for the dyes Sbt1 and Sbt3 fluorescence intensity is decreased to much lower extent as compared to optical density, for the dye Ref emission is suppressed almost as strongly as absorption (the difference between $\mathrm{D} / \mathrm{D}_{0}$ and $\mathrm{I} / \mathrm{I}_{0}$ for Ref is due to the nonlinear dependence of fluorescence intensity on optical density). Such difference between Ref and two other dyes corresponds to the difference between them in DNA effect on their photostability. In the case when the DNA-bound dye molecules are more photostable than the free ones, irradiation of dye-DNA solution leads to the destruction of mostly non-bound dye molecules. Since the emission intensity of DNA-bound dyes significantly exceeds that of the free dyes, such photodestruction makes stronger effect on dye absorption than on its emission. This feature

Table 3. Optical density (D) and fluorescence intensity (I) of dyes in the presence of dsDNA

\begin{tabular}{l|c|c|c|c}
\hline \multirow{2}{*}{ Dye } & \multicolumn{2}{|c|}{$\begin{array}{c}\text { Absorption, } \\
\mathrm{D} / \mathrm{D}_{0} \times 100 \%\end{array}$} & \multicolumn{2}{c}{$\begin{array}{c}\text { Fluorescence, } \\
\mathrm{I} / \mathrm{I}_{0} \times 100 \%\end{array}$} \\
\cline { 2 - 5 } & 0.5 hour & 2 hours & 0.5 hour & 2 hours \\
\hline Sbt1+DNA & $89 \pm 4$ & $42 \pm 19$ & $96 \pm 4$ & $77 \pm 6$ \\
\hline Sbt3+DNA & $75.2 \pm 1.4$ & $35 \pm 19$ & $97.3 \pm 1.4$ & $83 \pm 5$ \\
\hline Ref+DNA & $80 \pm 5$ & $44 \pm 4$ & $75.8 \pm 0.2$ & $55 \pm 6$ \\
\hline * 50 mM Tris-HCl buffer ( $p H 7.9$ ) (in \% from that of \\
non-irradiated sample, $D_{0}$ and $I_{0}$ respectively) after \\
irradiation by LED during 30 and 150 min. $C_{\text {dye }}=$ \\
$5 \mu M, C_{\text {dsDNA }}=61.5 \mu M$ b.p.
\end{tabular}


may be used for differentiation and contrast of structures stained by dyes that burn out more and less quickly.

\section{Determination of binding constant}

Based on the results of the dye fluorescence intensity increase in the dsDNA presence, we supposed above that increased photostability of the dyes Sbt1 and Sbt3 in the DNA presence is due to higher affinity of these dyes binding to DNA as compared to other studied dyes. To support this assumption, we have compared the affinity of dye binding to dsDNA for the dyes Sbt1 and Sbt6. Both dyes increase their fluorescence intensity upon the DNA binding, but while the presence of DNA strongly enhances the photostability of Sbt1, that of Sbt6 does not depend on the DNA presence. The equilibrium constant $\left(\mathrm{K}_{\mathrm{b}}\right)$ of binding to dsDNA was determined for Sbt1 in [12]; for Sbt6, $K_{b}$ was found here using the approximation of the dye fluorescent titrations by dsDNA with the equation (3) (Fig. 4), in the same way as it was done for Sbt1 in [12]. Thus, the values of $K_{b}$ for

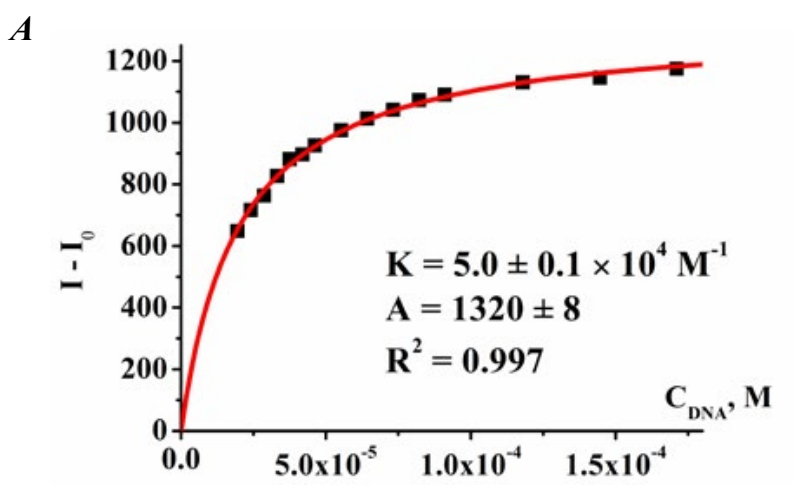

Stb1 and Sbt6 were found to be $5.0 \times 10^{4} \mathrm{M}^{-1}$ and $1.0 \times 10^{4} \mathrm{M}^{-1}$ respectively. Such values of $\mathrm{K}_{\mathrm{b}}$ are typical for intercalating dyes, the usual range being between $10^{4}$ and $10^{6} \mathrm{M}^{-1}$, while groove binders have higher binding constants $\left(10^{5}-10^{9} \mathrm{M}^{-1}\right)$ [18].

Since the $K_{b}$ value for Sbt6 is 5 times lower than the one for Sbt1, higher percent of dye molecules are bound to DNA in the case of the latter as compared to the former. For the obtained $\mathrm{K}_{\mathrm{b}}$ values and used concentrations (61.5 $\mu \mathrm{M}$ DNA and $5 \mu \mathrm{M}$ of dye), the rough estimation based on the mass action law results in $75 \%$ and $38 \%$ of the bound dye in the dyeDNA solution for Sbt1 and Sbt6 respectively. That may explain (at least partially) the fact that the DNA effect on the dye photostability was significant for Sbt1 and was not observed for Sbt6. Other alternative (or additional) explanations could be e.g. more rigid fixation in DNA or longer time of being bound (since dynamic equilibrium between free and DNAbound dyes takes place in dye-DNA solution) for Sbt1 as compared to Sbt6, or different

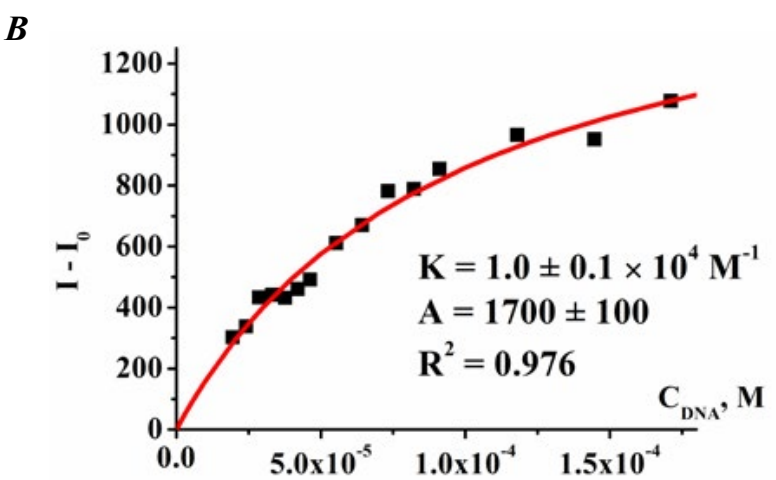

Fig. 4. Plots of $\left(\mathrm{I}-\mathrm{I}_{0}\right)$ dependence on $\mathrm{C}_{\mathrm{DNA}}$ (black squares) and its approximation by the Eq. (3) (red line) for Sbt1 (A) and Sbt6 $(B)\left(\mathrm{C}_{\text {dye }}=2 \mu \mathrm{M}, \mathrm{C}_{\mathrm{DNA}}=19.5-171 \mu \mathrm{M}\right)$. ( $\left(\mathrm{I}-\mathrm{I}_{0}\right)$ is the difference between the measured fluorescence intensity (I) of the dye $(2 \mu \mathrm{M})$ in the presence of dsDNA at the certain DNA concentration $\left(\mathrm{C}_{\mathrm{DNA}}\right)$ and fluorescence intensity of the free dye at $2 \mu \mathrm{M}$ concentration $\left(\mathrm{I}_{0}\right)$. 
mechanisms of fixation making different groups of the chromophore accessible to reactive oxygen species or redox-active molecules.

\section{Staining by the dyes}

Since the dye Sbt1 bearing N-alkylbenzylamine group has demonstrated rather high constant of binding to dsDNA, as well as strong increase in fluorescence intensity and photostability upon this binding, we have studied the possibility to use this dye as fluorescent stain for fluorescent microscopy. Thus, we have performed the staining of mesenchymal stem cells with Sbt1 in co-staining with DNAsensitive stain SYBR Green I (Fig. 5); the obtained images showed that Sbt1 brightly stains cytoplasm, so it could be suggested to visualize cytoplasmic RNA. The dye seemed to penetrate less efficiently into the nucleus, but nucleus components (probably nucleoli) stained by this dye were highly discernable. In contrast to styrylcyanine dye Sbt1, SYBR Green I stained mainly nucleus, and discrimination of nucleolus components with this dye was less pronounced (Fig. 5).

\section{Conclusions}

A series of the benzothiazole-based styrylcyanines functionalized with $\mathrm{N}$-alkyl tail groups of different nature was synthesized and characterized for their photostability and fluorescence response upon binding to nucleic acids. These styrylcyanine dyes are weakly fluorescent in the unbound state, whereas the presence of NA caused an increase of the dyes fluorescence intensity up to 83 times. The intensity of dye fluorescence response depends on N-alkyl tail substituent of the dye. The most significant enhancement was observed for the dyes with positively charged aromatic substituents Sbt1 (with N-alkyldimethylbenzyl substituent) and Sbt3 (with N-alkyldipyridyl substituent), the least significant - for the dyes with negatively charged groups Sbt7 (sulfosubstituent) and Sbt5 (carboxy-substituent).

The dyes Sbt1 and Sbt3 are, on one hand, the least photostable in a free state and, on the other hand, addition of DNA to these dyes results in strong increase of their photostability. The dyes, which either bear single positive
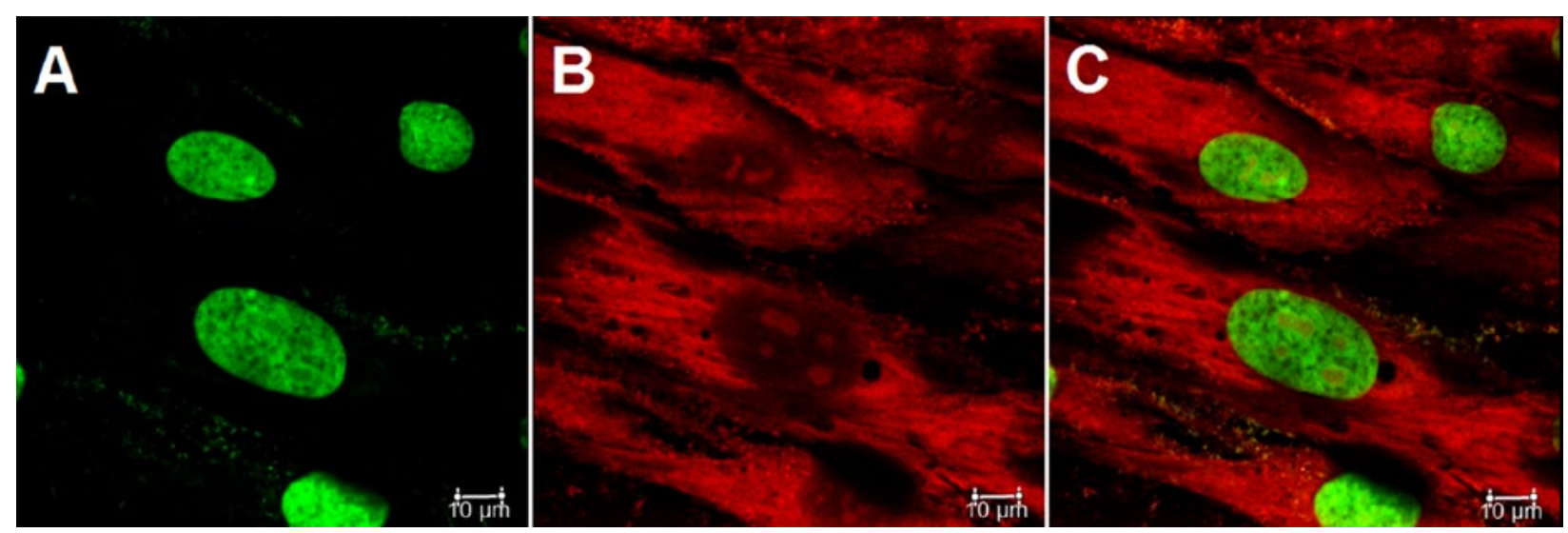

Fig. 5. Images of mesenchymal cells co-stained by Sbt1 and SYBR Green I: green emission of SYBR Green I (A), red emission of dye Sbt1 (B), and merging of both emissions (C). 
charge on chromophore (uncharged N-alkyl tail group) or are zwitterionic (due to negatively charged N-alkyl tail group), are more photostable when free, and the presence of DNA weakly affects their photostability. Thus, the charge and/or the nature of $\mathrm{N}$-alkyl tail group makes strong effect on the photostability of benzothiazole styrylcyanine dye in water solution. The dye bearing positively charged $\mathrm{N}$-alkyl tail groups binds to DNA with higher affinity (binding constant for Sbt1 is $5 \times 10^{4} \mathrm{M}^{-1}$ ) comparing to the dye Sbt6 with uncharged tail group (binding constant $10^{4} \mathrm{M}^{-1}$ ).

Staining of mesenchymal stem cells with the dye Sbt1 in co-staining with sensitive to DNA dye SYBR Green I has shown that Sbt1 brightly stains cytoplasm and nucleus components (probably nucleoli), whereas SYBR Green I stains mainly the nucleus. Presumably, Sbt1 is suggested to visualize cytoplasmic RNA and clusters of RNA in the nucleus.

Thus, variation of chemical nature of $\mathrm{N}$-alkyl tail group is a way to design styrylcyanine dyes of different photostability. Functionalized styrylcyanines are suggested as handy and photostable fluorescent stains for microscopy techniques and nucleic acid detection in solution.

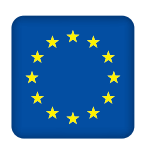

\section{Funding}

The project leading to these results has received funding from the European Union's Horizon 2020 research and innovation program under the Marie Skłodowska-Curie grant agreement no. 872331 .

\section{Conflicts of interest}

Authors declare no conflict of interests.

\section{REFERENCES}

1. Wiederschain GY. The Molecular Probes handbook. A guide to fluorescent probes and labeling technologies. Biochem. 2011; 76(11): 1276.

2. Deligeorgiev T, Kaloyanova $S$, Vaquero JJ. Intercalating cyanine dyes for nucleic acid detection. Rec Pat on Mat Sci. 2010; 2: 1-26.

3. Eggeling $C$, Widengren J, Rigler R, Seidel CAM. Photostability of Fluorescent Dyes for Single-Molecule Spectroscopy: Mechanisms and Experimental Methods for Estimating Photobleaching in Aqueous Solution. Springer. 1999; 10: 193-240.

4. Zheng $Q$, Lavis $L D$. Development of photostable fluorophores for molecular imaging. Curr Opin Chem Biol. 2017 Aug; 39: 32-38.

5. Oliveira E, Bértolo E, Núñez C, Pilla V, Santos HM, Fernández-Lodeiro J, Fernández-Lodeiro A, Djafari J, Capelo JL, Lodeiro C. Green and Red Fluorescent Dyes for Translational Applications in Imaging and Sensing Analytes: A Dual-Color Flag. ChemistryOpen. 2018; 7(1): 9-52.

6. Valverde-Aguilar $G$. Photostability of laser dyes incorporated in formamide $\mathrm{SiO} 2$ ORMOSILs. Opt Mater (Amst). 2006; 28(10): 1209-15.

7. Albota M, Beljonne D, Brédas J-L, Ehrlich JE, Fu J-Y, Heikal AA, Hess SE, Kogej T, Levin MD, Marder SR, McCord-Maughon D, Perry JW, Röckel H, Rumi M, Subramaniam G, Webb $W W, W u X-L$, $X u C$. Design of Organic Molecules with Large Two-Photon Absorption Cross Sections. Science (80- ). 1998; 281(5383): 1653 LP - 1656.

8. Fujita H, Nakano M, Takahata M, Yamaguchi K. A new strategy of enhancing two-photon absorption in conjugated molecules: Introduction of charged defects. Chem Phys Lett. 2002; 358435-41.

9. Wu L-Z, Tang $X-J$, Jiang $M-H$, Tung $C-H$. Twophoton induced fluorescence of novel dyes. Chem Phys Lett. 1999; 315(5): 379-82.10.

10. Bohländer PR, Wagenknecht HA. Bright and photostable cyanine-styryl chromophores with green and red fluorescence colour for DNA staining. $\mathrm{Me}$ thods Appl Fluoresc. 2015; 3(4): 1-5.

11. Tokar VP, Losytskyy MY, Ohulchanskyy TY, Kryvorotenko DV, Kovalska VB, Balanda AO, Dmy- 
truk IM, Prokopets VM, Yarmoluk SM, Yashchuk VM. Styryl Dyes as Two-Photon Excited Fluorescent Probes for DNA Detection and Two-Photon Laser Scanning Fluorescence Microscopy of Living Cells. J Fluoresc. 2010; 20(4): 865-72.

12. Kuperman $M V$, Snihirova $Y V$, Kryvorotenko $D V$, Losytskyy MY, Kovalska VB, Yarmoluk SM. N-alkylaryl styrylcyanine dyes as fluorescent probes for nucleic acids detection. Biopolym Cell. 2018; 34(5): 374-86.

13. Deligeorgiev T, Vasilev A, Kaloyanova $S$, Vaquero JJ. Styryl dyes - synthesis and applications during the last 15 years. Color. Tech. 2010; 126: 55-80.

14. Kurutos A, Zhytniakivska O, Trusova V, Tarabara U, Gorbenko G, Gadjev N, Deligeorgiev T. Novel asymmetric monomethine cyanine dyes derived from sulfobetaine benzothiazolium moiety as potential fluorescent dyes for non-covalent labeling of DNA. Dyes and Pigm. 2016; 130: 122-128.

15. Bałanda M, Rams M, Nayak SK, Tomkowicz Z, Haase W, Tomala K, Yakhmi J V. Slow magnetic relaxations in the anisotropic Heisenberg chain compound $\mathrm{Mn}(\mathrm{III})$ tetra(ortho-fluorophenyl)porphyrintetracyanoethylene. Phys Rev B. 2006; 74(22): 224421.

16. McGhee JD, von Hippel $P H$. Theoretical aspects of DNA-protein interactions: Co-operative and non-cooperative binding of large ligands to a one-dimensional homogeneous lattice. J Mol Biol. 1974;86(2):469-89.

17. Shuvalova $N$, Kordium $V$. Morphological characteristics of mesenchymal stem cells from wharton jelly, cultuivated under physiological oxygen tensions, in various gas mixtures. Biopolym Cell. 2016; 32(4): 262-70.

18. Ihmels $H$, Otto D. Intercalation of Organic Dye Molecules into Double-Stranded DNA-GeneralPrinciples and Recent Developments BT - Supermolecular Dye Chemistry. Springer. 2005;258:161-204.

\section{Варіація фотостабільності ДНК-чутливих стирилціанінових барвників, зумовлена природою $\mathbf{N}$-алкільних замісників}

Є. В. Снігірьова, М. Ю. Лосицький,

Д. В. Криворотенко, М. В. Куперман, О. В. Мошинець, С. М. Ярмолюк, А. Мохір, В. Б. Ковальська

Мета. Синтез та характеризація серії $\mathrm{N}$-алкільних функціоналізованих бензтіазол стирилціанінових барв- ників у якості потенційних фотостабільних зондів для детекції нуклеїнових кислот (НК). Методи. Синтез, спектроскопія поглинання і флуоресценції, опромінення барвників видимим світлом, конфокальна мікроскопія. Результати. Барвники, що мають слабку флюоресценцію у вільному стані, підвищують інтенсивність емісію при зв'язуванні з ДНК до 83 разів; найбільше підвищення спостерігалось для барвників 3 позитивно зарядженими $\mathrm{N}$-алкільними замісниками Sbt1 и Sbt3. Барвники Sbt1 и Sbt3 виявились найменш фотостабільними у вільному стані, але додавання ДНК значно підвищило їх фотостабільність. Барвники 3 незарядженими та негативно зарядженими $\mathrm{N}$-алкільними замісниками є більш фотостабільними в незв'язаному стані, і присутність ДНК значно не впливає на іх фотостабільність (зокрема завдяки слабкій взаємодії з ДНК барвників з негативно зарядженим замісником). При фарбуванні мезенхімальних ставбурових клітин, Sbt1 яскраво забарвлював цитоплазму та компоненти ядра (можливо, ядерця), так що імовірно він фарбує цитоплазматичну РНК та кластери РНК у ядрі. Висновки. Варіація хімічної природи $\mathrm{N}$-алкільних замісників $\epsilon$ способом створення стирилціанінових барвників з різною фотостабільністю. Функціоналізовані стирилціанінові барвники є перспективними як легкі в застосуванні флуоресцентні зонди для детекції нуклеїнових кислот у розчині та візуалізації РНК-містких об’єктів у мікроскопії.

К л юч о в і с л о в а: Флуоресценція, стирилціаніни, детекція НК, фотостабільність, мкроскопія.

\section{Изменение фотостабильности ДНК- чувствительных стирилцианиновых красителей, обусловленное природой $\mathbf{N}$-алкильных заместителей}

Е. В. Снигирёва, М. Ю. Лосицкий, Д. В. Криворотенко, М. В. Куперман, Е.В. Мошинец, С. Н. Ярмолюк, А. Мохир, В. Б. Ковальская

Цель. Синтез и характеризация серии $\mathrm{N}$-алкил функционализированных бензтиазол стирилцианиновых красителей как потенциальных фотостабильных зондов для детекции нуклеиновых кислот (НК). Методы. Химический синтез, спектроскопия поглощения и флуоресценции, облучение красителей видимым светом, 
Y. V. Snihirova, M. Yu. Losytskyy, D. V. Kryvorotenko et al.

конфокальная микроскопия. Результаты. Слабо флуоресцирующие в свободном состоянии, красители повышают интенсивность эмиссии при связывании с ДНК до 83 раз; наибольшее повышение наблюдалось для красителей с позитивно заряженным Т-алкильным заместителем - Sbt1 и Sbt3. Красители Sbt1 и Sbt3 оказались наименее фотостабильными в свободном состоянии, но добавление ДНК значительно увеличило их фотостабильность. Красители с незаряженными и негативно заряженными $\mathrm{N}$-алкильными заместителями более фотостабильны в несвязанном состоянии, и присутствие ДНК слабо влияет на их фотостабильность (в частности благодаря слабому взаимодействию с ДНК красителей с негативно заряженным заместителем). При окрашивании мезенхимальных стволовых клеток,
Sbt1 ярко окрашивал цитоплазму и компоненты ядра (возможно, ядрышки), так что предположительно он окрашивает цитоплазматическую РНК и кластеры РНК в ядре. Выводы. Изменение химической природы $\mathrm{N}$-алкильных заместителей является способом создания стирилцианиновых красителей различной фотостабильности. Функциализированные стирилцианиновые красители являются перспективными в качестве легких в использовании флуоресцентных зондов для детекции нуклеиновых кислот в растворе и визуализации РНКсодержащих объектов в микроскопии.

Кл юч е в ы е с л о в а: Флуоресценция, стирилцианины, детекция НК, фотостабильность, микроскопия.

Received 04.02.2020 